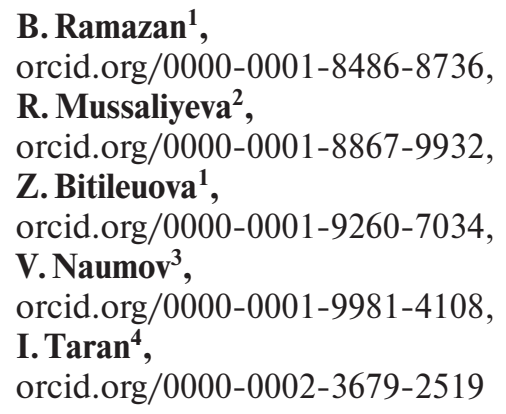

1 - Kazakh Academy of Transport and Communications, Almaty, the Republic of Kazakhstan

2 - Turan University, Almaty, the Republic of Kazakhstan

3 - Cracow University of Technology, Krakow, the Republic of Poland

4 - Dnipro University of Technology, Dnipro, Ukraine e-mail: taran7077@gmail.com

\title{
CHOOSING THE LOGISTICS CHAIN STRUCTURE FOR DELIVERIES OF BULK LOADS: CASE STUDY OF THE REPUBLIC KAZAKHSTAN
}

Purpose. The paper aims to develop the methodology for choosing the best available structure of a logistics chain for deliveries of bulk cargoes.

Methodology. The systematic approach is used to formalize the problem of choosing the optimal structure of a logistics chain: the total expenses are used to define the goal function, alternative logistics chain structures and numeric parameters of the request flow (the delivery distance and the consignment weight) are defined as control variables, and the random variables representing technological parameters of servicing processes are used to consider the influence of the environment on the logistics chain. The mathematical model defines the functional dependence of the total expenses on the entities within the delivery chain on the request flow parameters for two alternative structures: the delivery with transshipment in one freight terminal and the delivery through two terminals. By using functional analysis, we define the ranges of the request flow parameters where the use of a given logistics chain structure is characterized by minimal total expenses.

Findings. The experimental studies conducted considering two alternative logistics chain structures have shown that the better solution varies depending on the values of the request parameters. It allowed us to state that the ranges of the numeric parameters of the request flow may be defined to substantiate the optimal logistics chain structure for deliveries of bulk loads.

Originality. The dependencies of the total logistics expenses on the delivery distance and the consignment weight as the parameters of the flow of requests for bulk cargo transportation have been defined in the paper for the first time.

Practical value. The proposed methodological approach can be used by freight forwarders to substantiate the best option out of available alternative structures of a logistics chain for deliveries of loads with the given delivery distance and the consignment weight.

Keywords: logistics chain structure, freight forwarding, total logistics expenses, a flow of requests

Introduction. Bulk cargo transportation for countries with a developed mining and agricultural industry is the most massive type of transportation. Ensuring a continuous flow of goods with the lowest transportation costs while meeting the main criteria for the delivery quality (delivery time and safety of goods) is the main task for transport and forwarding companies.

Today, for most post-socialist transition economies, the use of agriculture is widely recognized as a promising development strategy for the state. In recent years, the economic development of Kazakhstan has been associated with agricultural enterprises as one of the key sectors. The share of the agricultural sector in the country's economy in 2019 amounted to $4.5 \%$ of GDP [1]. Agricultural land covers more than $846000 \mathrm{~km}^{2}$ and comprises $205,000 \mathrm{~km}^{2}$ of arable land and $611000 \mathrm{~km}^{2}$ of pastures and hayfields. More than $80 \%$ of the total area of the country is agricultural land.

The current stage of development of the agricultural industrial complex is characterized by the desire to maximize the conjugation of logistics operations by all participants in the supply chains. Typically, agriculture has a complex supply chain structure that, from collection and transportation to storage and distribution, must be well structured and optimized. As constraints in optimization, it is necessary to consider the time constraints for planting, harvesting, and transport operations related to seasonality. Besides, manufacturing, processing, packaging, warehousing, and transportation are inextricably linked to management, control, information, and capital.

The promptness and timeliness of the supply of agricultural products are some of the most important issues related to

(C) Ramazan B., Mussaliyeva R., Bitileuova Z., Naumov V., Taran I., 2021 the conditions and timing of shipment, on the one hand, and the constant and massive demand for products, on the other. The main problem here lies in considering the stochastic parameters of the demand for daily supplies. As an example, in the research [2], the supply chain of a company, facing demand disruptions, is considered as a case study. For this purpose, a multi-stage stochastic integer programming model is proposed and solved using a customized progressive hedging algorithm. Moreover, the effect of uncertainty on the supply chain performance is measured using the value of the stochastic solution and the expected value of perfect information metrics. Another significant problem arising in the process of organizing deliveries of bulk cargo is the choice of the optimal logistics chain (LC). In this case, the optimal solution should be substantiated based on the predefined set of alternative LC structures. The choice of the delivery scheme that ensures the minimum total costs of the logistics chain entities is proposed in the paper [3]. The author considers four alternative LC structures for deliveries by road transport and proposes the methodology of calculating the total expenses within the logistics chain. The methodology for the calculation of the total expense given in [3] is also used in the current paper for the substantiation of the optimal solution regarding the choice of the LC structure for deliveries of bulk loads.

Literature review. Recently, Green Supply Chain Management (GSCM) has become one of the most important approaches in the supply chain. GSCM is characterized by faster delivery, shorter waiting times, and improved quality and environmental performance. The research [4] describes a GSCM assessment model for the distribution of agricultural products in cities. The timeliness of the supply of agricultural products affecting food security is assessed as a complex phenomenon with climatic, economic, and infrastructural aspects. To con- 
sider the influence of seasonality and regional distribution networks on the efficiency of agricultural supplies, the Food Distributed Extendable Complementarity model was developed by the authors of the paper [5], which describes a combination of agricultural and transport systems.

Emergency supplies of fresh agricultural produce are critical to supporting residents in the face of large-scale epidemics such as the COVID-19 pandemic. Various optimization models, considering the growing demand and limited transport resources, are developed to jointly determine the parameters of the processes of optimal planning, packaging, vehicle assignments, and delivery routes. Another area of research is the construction of a network structure of the supply chain, considering the labour constraints that arise during the transportation cycle. To study the driving forces of a sustainable supply chain in order to eliminate disruptions in it during a pandemic, various authors propose methodologies based on Pareto analysis, fuzzy theory, total interpretive structural modelling, and methods of multiplication by matrix criteria for assessment and classification. Building on current experiences with the COVID-19 pandemic, various studies highlight the need to promote marketing channels that generate income for farmers while facilitating consumer access to agri-food products when the main distribution channels are not serving them. The work [6] is devoted to the issues of reducing the amount of food transported from agricultural land and expanding urban agriculture. The paper [7] aims to develop an appropriate agricultural products logistics scheme that is sustainable and addresses the identified challenges considering the necessity of freight villages. In coordination with the freight villages, two other transformations are proposed, i.e., farmers' co-ops and supermarkets or chain stores.

Hundreds of millions of agricultural products are lost annually during transportation. The optimal location of the transportation network node is of great practical importance for increasing the efficiency of transportation and ensuring the freshness of agricultural products. A pure hierarchical hub and spoke transport network is used to simulate the transport of agricultural products; a genetic algorithm with two levels of chromosome coding is applied to select the optimal nodes that guarantee on-time delivery. Exploring a network model of a lean supply chain based on the elimination of nodes suggests that a large number and variety of nodes are the main causes of structural complexity. The paper [8] proposes a description rule and an evolutionary algorithm of a dumbbell-shaped multi-echelon supply chain complex network based on node degree preference and the connection preferences of competitive advantage coefficient.

Nowadays, with hundreds of millions of tons of agricultural products sold annually around the world, it is imperative to ensure that the products supplied are safe, of satisfactory quality, and supplied in the required quantities. Trends like globalization, shorter product life cycles, and cost reduction strategies in the global business environment have exposed many supply chains to various risks. Based on the current situation of China's agricultural supermarket supply chain development, the paper [9] make an in-depth study on the supply chain risk of agricultural products of large retail enterprises under the mode of "agricultural supermarket docking", and then introduces the agricultural supermarket docking supply chain under the big data environment. In the paper [10], its authors propose a new model for supply chain risk propagation considering herd mentality and risk preference under warning information on multiplex networks, in which one layer is used to denote the risk propagation and the other one represents the warning information propagation network. The context of the sustainable supply chain is progressively getting attention among supply chain managers due to its competitive advantage in firms' performance. Increasing supply chain complexity is argued as one of the biggest risks in achieving the organizational goal with an adverse impact on operational ef- ficiency, cost, profitability, on-time delivery, and customer satisfaction. Finally, the paper [11] suggests carefully designing measures to improve transportation technical efficiency according to regional economic development orientations.

The growth of the productive sector has driven the evolution of supply chains into highly complex, dynamic, and concurrent systems. Consequently, emerging structures have been developed through the integration of advances in information and hardware technologies to increase effectiveness and efficiency, as Industry 4.0 [12]. The authors discuss the specifics of production planning and supply chain management under the conditions of Industry 4.0. The authors determine regional models of planning of production and supply chain management that exist in the modern global economy - the European and American model, the Asian model, and the Eurasian model (Kazakhstan, Georgia). The necessity for creating a new framework model of production planning and supply chain management under the conditions of Industry 4.0 is substantiated, and practical recommendations for adapting this model to the specifics of regions of the world are offered.

The circulation efficiency of the fresh agricultural product supply chain is greatly influenced by the purchasing power of end consumers. In the paper [13], a method to coordinate a fresh agricultural product supply chain with the consideration of strategic consumer behavior is proposed. The objective of the paper [14] is to present the general idea of implementing a fourth-party logistics service provider into a transportation (planning) process, to clarify the different functions of the participating parties, and to introduce the modified transportation planning process as an artifact. The research [15] undertakes the study on an integrated production-inventory and pricing decision problem for a single manufacturer-multiple buyer supply chain where each buyer faces price-dependent demand. Associated problems, formulated as mixed-integer non-linear programming problems, are computationally very hard, and thus evolutionary heuristics as genetic algorithm and teaching-learning based optimization are proposed.

When planning the distribution of agricultural goods, strict timing must be in place to ensure that safe, fresh, and high-quality product is delivered to customers. In the paper [16], 14 causes of food loss and waste in fruit and vegetable supply chains were identified and divided into seven levels of influence, by the Interpretive Structural Modelling methodology, showing that the logistic related causes have a major influence on the others.

The optimization problem of marketing planning for agricultural products based on the degree of maturity was built in [17] based on the ant colony algorithm. The study [18] describes the closed-loop supply chain that consists of a manufacturer and a distributing center that are producing and distributing a deteriorating product to customers. The deteriorating products are collected from the distribution center and made available by the producer. This closed-loop supply chain, which consists of four main sub-systems, is simulated using the system dynamics. The relevant mixed-integer linear programming models are being developed to make supplier selection, location-allocation, transportation mode, assembly technology, and recovery level decisions. Given that the strategic and tactical decisions in a closed-loop supply chain are largely influenced by uncertainties, finding robust solutions is of great importance. In the paper [19], its authors present the models and the respective solution methods for supply chain network design that not only integrate the location-transportation and inventory problems but also consider the implementation of coordinated inventory control in the network. The problems of organizing freight transport processes in the Republic of Kazakhstan (but not including deliveries of bulk or agricultural cargoes) were considered and solved by the authors in the papers $[20,21]$.

Unsolved aspects of the problem. The completed review of the existing approaches to improving the efficiency of the bulk 
transportation processes allows us to highlight the following disadvantages:

- most of the developed methods do not consider the stochastic nature of the demand for deliveries;

- the existing optimization approaches are focused on the separated technological processes (loading operations, transport, or warehousing processes);

- the optimization techniques used to enhance the processes within supply chains do not usually consider the structure of the delivery system.

In this paper, we contribute to the direction of increasing the efficiency of bulk cargo transportation. We aim to fill the gap in the existing methodology for the substantiation of the LC structure concerning deliveries of bulk loads on a mass scale (by considering the example of the transportation of the agricultural products)

Purpose. The goal of this study is to develop a methodology for choosing the optimal structure of a logistics chain for deliveries of bulk loads based on a set of alternative structures.

The object of the research is the process of bulk cargo transportation within the supply chain, and the subject is the process of choosing the structure of the logistics chain out of the set of alternative solutions. The substantiation of the optimal LC structure is completed by an organizer of the delivery (as a rule, by a freight forwarding company). For this, the forwarding company defines the alternative variants for the given parameters of the delivery request. Our study develops the methodology serving as a tool supporting the forwarder in deciding on the choice of the proper LC structure.

To achieve the goal of the study, we identify alternative structures of the delivery schemes representing the logistics chains for deliveries of bulk loads. Then, we describe the structure of the expenses for the LC entities and define the functional dependencies of the total expenses on the key numeric parameters representing the requests for deliveries. Finally, we show the example of choosing the optimal LC structure for the case of the delivery of agricultural loads in Kazakhstan.

Model of a delivery chain. The process of choosing the optimal supply chain structure can be presented as a cybernetic model: a set of incoming parameters, in this case, should be described by the basic numerical characteristics of a delivery request - the consignment weight $Q$ and the delivery distance $L$ [22]; the influence of environmental factors may be described by the set of parameters $\{T\}$ characterizing the technological processes of entities within the delivery chain (in the mathematical model, these parameters are realizations of random variables of the delivery speed, the time of specific technological operations, non-production vehicle downtime, and so on). The result of the choice is such a structure $L C_{o p t}$, for which the value of the considered efficiency criterion is optimal.

When solving problems at the macro-logistical level, it is advisable to use the total costs of the entities that form the delivery chain as the efficiency criterion. In this case, the problem of choosing the optimal LC structure can be formalized, as follows

$$
L C_{o p t}=\arg \min _{L C} E_{T}(L C),
$$

where $E_{T}$ is the total costs of all entities participating within the logistics chain with the given structure $L C$.

The total costs within the delivery chain are functionally determined by a set of input parameters and the parameters describing the influence of the external environment on the logistics system

$$
E_{T}=f(L C, Q, L,\{T\}) .
$$

The mandatory elements of any delivery chain are the freight owners - a consignor $F O^{[A]}$ and a consignee $F O^{[B]}$. The LC also contains at least one forwarder and one carrier. Freight terminals may also be included as the elements of a complex delivery chain with the participation of several carriers and freight forwarders. A customs point should be considered in the case of international delivery of goods, as a specific element, whose presence determines the structure of expenses for other participants in the supply chain. In general, the LC structure can be formalized, as follows

$$
L C=\left\{F O^{[A]},\{C\},\{F T\},\{F F\}, F O^{[B]}\right\},
$$

where $\{C\}$ is the set of carriers; $\{F T\}$ is the set of freight terminals; and $\{F F\}$ is the set of freight forwarding companies.

The choice of the optimal delivery chain structures should be performed based on a set of alternatives. Let us define the basic variants of the LC structures for deliveries of bulk cargoes.

For a given LC being an element of a logistics system, the initial entity that generates the flow of requests for deliveries is a freight owner (consignor), and the end entity is the other freight owner (consignee). Physically, a carrier performs the processing of the material flow. The organization of the material flow processing is implemented by a freight forwarder using, if necessary, the resources of cargo terminals. As an organizer of the technological processes, a freight forwarder is an element of LC, which concentrates information flows. Since the freight owner, to fulfill their need in goods delivery, addresses the freight forwarder, the cash flow in the LC passes initially from the owner to the freight forwarder, and then to the other participants in the chain.

The freight terminal is involved in processing the material flow in the $L C^{[1 T]}$ variant of the logistics chain (1T-type chain) represented by a set of six basic elements

$$
L C^{[1 T]}=\left\{\begin{array}{l}
F O^{[A]}, C_{1}^{[A]}, C_{2}^{[A]}, \\
F F^{[A]}, F T^{[A]}, F O^{[B]}
\end{array}\right\},
$$

where $C_{1}^{[A]}$ is a carrier in the consignor's region ensuring the delivery of freight to the terminal; $C_{2}^{[A]}$ is a carrier in the consignor's region that provides long-distance delivery; $F T^{[A]}$ is a cargo terminal in the consignor's region (region $A$ ).

After receiving the request from the freight owner, the freight forwarder estimates the feasibility of transport of a shipment with a freight terminal involved in the delivery chain. If such a variant of the chain structure is economically feasible, then the forwarder searches for carriers for delivering cargo to the terminal and for directly exporting the enlarged shipment for delivery to the consignee. Four bilateral agreements are signed after determining the parties of the shipment process: between the forwarder and the shipper, between the forwarder and the regional carrier, between the forwarder and the freight terminal, and between the forwarder and the carrier that implements the long-distance delivery. Of the funds that are received by the freight forwarder from the freight owner, the forwarder pays for the services of carriers and the freight terminal. This variant of the LC is usually used when a consignment is delivered to the terminal by automobile transport, consolidation of shipments by directions, and subsequent delivery by the main transport (e.g., by the rail carrier). It is also possible that the freight terminal organizes the export of the enlarged shipment, implementing the functions of a forwarder at the transport services market.

A more common option for bulk cargo delivery with the participation of long-distance transport is the variant of a delivery chain structure with two freight terminals involved.

The two-terminal LC variant $L C^{[2 T]}$ ( $2 T$-type chain) is the following set of elements

$$
L C^{[2 T]}=\left\{\begin{array}{l}
F O^{[A]}, C_{1}^{[A]}, C_{2}^{[A]}, F F^{[A]}, F T^{[A]}, \\
F F^{[B]}, C^{[B]}, F T^{[B]}, F O^{[B]}
\end{array}\right\},
$$

where $F F^{[B]}$ is the freight forwarder in the consignee's region (region $B) ; F T^{[B]}$ is a cargo terminal in the region $B$.

In this case, the freight owner declares their need to deliver a consignment. The freight forwarder, having received the re- 
quest, concludes that of the many alternative options for the logistics chain structure, the option with two cargo terminals will be the most effective one. After that, the freight forwarder determines the regional carrier for e delivery of the shipment from the shipper to the terminal, concludes an agreement with the terminal and the main carrier, and then also sends a request for the delivery of the shipment to a foreign partner forwarder. The partner forwarder organizes the delivery of the consignment from a terminal in his region to the consignee. For this, it determines the regional carrier and enters into an agreement with the terminal. For this LC variant, the following agreements are signed: in the consignor region - between the freight forwarder and the cargo owner, between the forwarder and the regional carrier, between the forwarder and the cargo terminal in the sender's region, and between the forwarder and the international carrier; in the consignee's region - between the forwarder and the cargo terminal in the recipient region, between the forwarder and the regional carrier; also, a contract is concluded between the two forwarders. The freight forwarder in the sender's region from the remuneration received from the freight owner pays for the services of regional and international carriers, the terminal in their region, as well as the partner forwarder services. The freight forwarder in the recipient's region pays for the services of the terminal and the carrier in their region from the funds that are received from the first freight forwarder. It is also possible that the terminal pays the carrier's services in the sender's region, and the carrier's services for delivering the consignment to the consignee are paid by the freight terminal in the recipient's region.

As for the defined efficiency criterion, its main partials are the expenses of the corresponding entities participating in the delivery process. Below we present the structure of expenses defined in the paper [3].

Possible cost items for a freight forwarding company as an organizer of the delivery process within the logistics chain are the following:

- costs of finding a client;

- costs associated with the preparation of documentation for the delivery of a consignment from a consignor to a consignee; - costs of finding the partner organizations - a carrier, partner forwarder (if appropriate), 3PL-provider (if appropriate);

- costs of the organization and implementation of loading and unloading procedures;

- costs of the services provided by carriers;

- expenses for payment of the 3PL-provider (providers) services;

- customs payments;

- tax deductions.

The main items of costs for a freight owner are the following:

- costs of forming a transport package;

- losses due to freezing of funds that constitutes the shipment value;

- payment for the services of forwarders.

The carrier, providing the process of transportation of a consignment, is characterized by the following cost items:

- direct costs of delivery operations;

- costs of idle time under loading and unloading;

- costs of idle time in the customs point;

- tax deductions.

Freight terminals, performing the main function of consolidation and disaggregation of consignments, are characterized by the following costs:

- costs of transshipment (unloading and loading);

- costs of the formation and disbandment of transport packages;

- costs of interim storage operations;

- tax deductions.

We obtain the sum of the costs for the elements of the chain while considering the efficiency criterion at the aggregate level of a logistics chain

$$
\begin{gathered}
E_{T}^{[1 T]}=E_{F O}^{[A]}+E_{C 1}^{[A]}+E_{C 2}^{[A]}+E_{F F}^{[A]}+E_{F T}^{[A]}+E_{F O}^{[B]} ; \\
E_{T}^{[2 T]}=E_{F O}^{[A]}+E_{C 1}^{[A]}+E_{C 2}^{[A]}+E_{F F}^{[A]}+E_{F T}^{[A]}+E_{C}^{[B]}+E_{F T}^{[B]}+E_{F O}^{[B]},
\end{gathered}
$$

where $E_{L C}^{1 T}$ and $E_{L C}^{2 T}$ are the total costs for $1 T$ - and $2 T$-variants of the LC structure.

The functional dependence of the effectiveness criterion on the parameters of the flow of requests for cargo deliveries is substantiated in the paper [3] based on the presented methodology for calculating the total expenses. To substantiate this, the costs of LC elements were defined as a function of the request flow parameters to present the costs of the $j^{\text {th }}$ participant for servicing of the $i$ th request in the form $E_{T}^{[j]}=f\left(Q_{i}, L_{i}\right)$.

For the considered LC structures for deliveries of bulk loads, the total costs of all the participants of the delivery process given by equations $(1,2)$, while considering the resulting functional dependencies, take the following form

$$
\begin{gathered}
E_{T}^{[1 T]}=a_{0}^{1 T}+a_{Q 2}^{1 T} \cdot Q^{2}+a_{Q L}^{1 T} \cdot Q \cdot L+a_{Q}^{1 T} \cdot Q+ \\
+\left(a_{L}^{[A]} \cdot L^{[A]}+a_{L}^{[B]} \cdot L^{[B]}\right)+Q \cdot\left(a_{Q L}^{[A]} \cdot L^{[A]}+a_{Q L}^{[B]} \cdot L^{[B]}\right) ; \\
E_{T}^{[2 T]}=a_{0}^{2 T}+a_{Q 2}^{2 T} \cdot Q^{2}+a_{Q L}^{2 T} \cdot Q \cdot L+a_{Q}^{2 T} \cdot Q+ \\
+\left(a_{L}^{[A 1]} \cdot L^{[A 1]}+a_{L}^{[A 2]} \cdot L^{[A 2]}+a_{L}^{[B]} \cdot L^{[B]}\right)+ \\
+Q \cdot\left(a_{Q L}^{[A 1]} \cdot L^{[A 1]}+a_{Q L}^{[A 2]} \cdot L^{[A 2]}+a_{Q L}^{[B]} \cdot L^{[B]}\right),
\end{gathered}
$$

where $a_{0}^{j}, a_{Q 2}^{1 T}, a_{Q L}^{j}, a_{Q}^{j}$, and $a_{L}^{j}$ are the coefficients of the functional dependency of the total costs on the request parameters for the $j^{\text {th }}$ LC structure; $L^{[A 1]}, L^{[A 2]}, L^{[A]}$, and $L^{[B]}$ are the delivery distances covered by carriers in the sender region $\left(L^{[A 1]}, L^{[A 2]}\right.$, or $\left.L^{[A]}\right)$ and in the recipient region $\left(L^{[B]}\right)$.

It should be noted that the delivery distance that is covered by various carriers for the considered LC variants is determined based on the parameter $L$. Thus, for the considered $1 T$ and $2 T$-structures, the following conditions are fulfilled

$$
\begin{gathered}
L=L^{[A]}+L^{[B]} ; \\
L=L^{[A 1]}+L^{[A 2]}+L^{[B]} .
\end{gathered}
$$

As can be seen from $(3,4)$, the total costs of entities within a delivery chain quadratically depend on the consignment weight and the delivery distance. If in the considered range of the request parameter, there is a point of intersection of a pair of functions from $(3,4)$, then there exist areas of preferred use of the corresponding LC structures [3].

Results of experimental studies. Experimental studies were conducted based on the Joint Stock Company PlodEx (Almaty, Kazakhstan). The company's specialization is the distribution of agricultural loads at the national and international levels. Considering the company's tariffs and average indicators of the freight transportation market of Kazakhstan, we have evaluated the coefficients of the dependencies (3) and (4). The results of the evaluation are presented in Table for each of the alternative $\mathrm{LC}$ structures. The values of the coefficients are presented in Kazakhstani tenge (KZT) - the national currency of Kazakhstan.

By using the obtained numeric values of the coefficients defining functional dependencies for the evaluation of the efficiency criterion, the values of the total expenses were defined for both types of the delivery chain structure for the following ranges of the demand parameters:

- the delivery distance values were considered in the range between 100 and $1500 \mathrm{~km}$ with the step in $200 \mathrm{~km}$;

- the consignment weight values were varied in the range between 10 to 80 tons with the step of 10 tons.

As a result, the matrices of the efficiency criterion for the considered LC structures were obtained. The graphical representation of the total expenses dataset for the $1 T$-structure of the delivery chain is shown in Fig. 1.

If the value of one of the demand parameters is fixed, the functions of the total expenses may intersect in the considered 
Initial data for numeric simulations

\begin{tabular}{|l|c|c|}
\hline \multirow{2}{*}{ Parameter value } & \multicolumn{2}{|c|}{ LC structure } \\
\cline { 2 - 3 } & $1 T$ & $2 T$ \\
\hline$a_{0},[\mathrm{KZT}]$ & 127500 & 130000 \\
\hline$a_{Q 2},\left[\mathrm{KZT} / \mathrm{ton}^{2}\right]$ & 3.5 & 2.5 \\
\hline$a_{Q L},[\mathrm{KZT} /$ ton-km] & 0.2 & 0.075 \\
\hline$a_{Q},[\mathrm{KZT} /$ ton $]$ & 15 & 10 \\
\hline$a_{L}^{[A 1]},[\mathrm{KZT} / \mathrm{km}]$ & 0.5 & 0.5 \\
\hline$a_{L}^{[A 2]},[\mathrm{KZT} / \mathrm{km}]$ & 0.5 & 0.5 \\
\hline$a_{L}^{[B]},[\mathrm{KZT} / \mathrm{km}]$ & 0.5 & 0.6 \\
\hline$a_{Q L}^{[A 1]},[\mathrm{KZT} /$ ton-km] & 0.05 & 0.04 \\
\hline$a_{Q L}^{[A 2]},[\mathrm{KZT} /$ ton-km] & 0.05 & 0.035 \\
\hline$a_{Q L}^{[B]},[\mathrm{KZT} /$ ton-km] & 0.06 & 0.065 \\
\hline
\end{tabular}

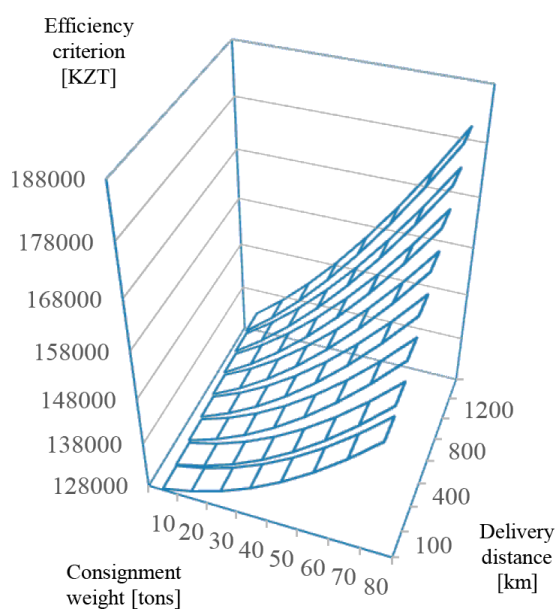

Fig. 1. Dependence of the total expenses on the request parameters for 1T-structure of the logistics chain

range of the other demand parameter. Such examples are shown in Fig. 2 (for the consignment weight) and Fig. 3 (for the delivery distance): the functions representing the efficiency criterion intersect at the point of 32.88 tons if the delivery distance is fixed at the value of $300 \mathrm{~km}$, and the functions intersect at the point of $792 \mathrm{~km}$ for the fixed consignment weight of 20 tons. That allows us to define the areas of preferred use of the considered LC structures: e.g., 1T-structure is the preferred variant for the values of the consignment weight up to 32.88 tons at the case presented in Fig. 2, and this LC structure is the preferred choice if the delivery distance is less than $792 \mathrm{~km}$ for the example in Fig. 3.

Conclusions. The proposed methodology for evaluating the efficiency of the alternative delivery chain structures allows for considering the stochastic nature of the cargo delivery process by presenting the parameters of demand and technological indicators as random variables. In practice, the simulation of the delivery technological processes should be performed to choose the best option for the LC structure. However, the proposed methodology allows decision-makers to avoid simulation routines by choosing the best option for the given numeric characteristics of demand parameters.

Functional analysis of influence of the demand parameters on the delivery chain efficiency showed that, for the considered structures, the total expenses quadratically depend on the consignment weight and linearly - on the delivery distance.

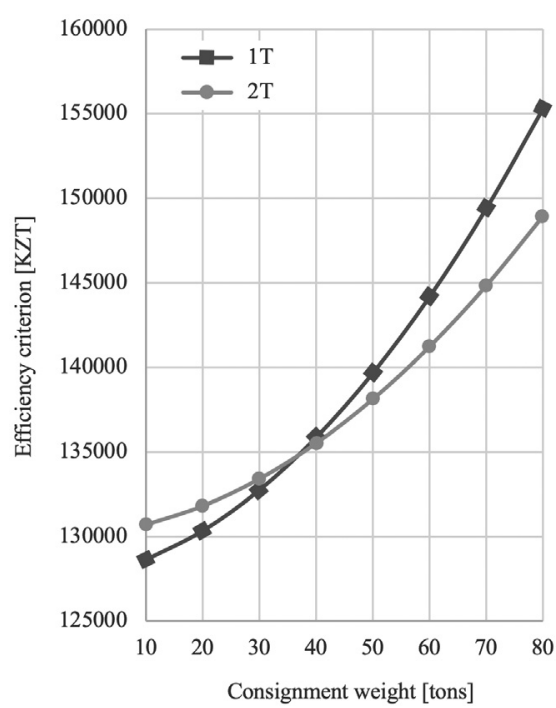

Fig. 2. Dependence of the total expenses on the consignment weight (delivery distance is $300 \mathrm{~km}$ )

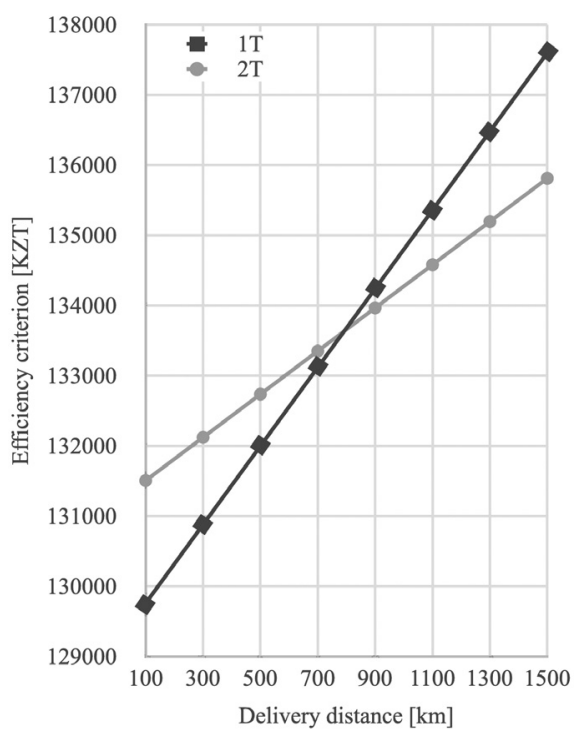

Fig. 3. Dependence of the total expenses on the delivery distance (the consignment weight is 20 tons)

The presented example of the assessment of the areas of the preferrable use for the considered LC structures shows that the 1T-structure is the optimal solution for smaller values of the consignment weight and the delivery distance.

As the directions of future research on the topic, the formation of the wider set of alternative LC structures for the deliveries of bulk loads and justification of the areas of their efficient use should be mentioned. The presented numeric results are case-sensitive and refer to freight deliveries by road transport within the bound of Kazakhstan, which means that additional experimental studies are needed to prove the obtained regularities.

\section{References.}

1. Agency for Strategic planning and reforms of the Republic of Kazakhstan Bureau of National statistics (n.d.). Retrieved from http://stat.gov.kz. 2. Ghorashi Khalilabadi, S.M., Zegordi, S.H., \& Nikbakhsh, E. (2020). A multi-stage stochastic programming approach for supply chain risk mitigation via product substitution. Computers \& Industrial Engineering, (149), 106786. https://doi.org/10.1016/j.cie.2020.106786. 3. Naumov, V. (2020). Substantiating the logistics chain structure while servicing the flow of requests for road transport deliveries. Sustainability, 12(4), 1635. https://doi.org/10.3390/su12041635. 
4. Rajabion, L., Khorraminia, M., Andjomshoaa, A., GhafouriAzar, M., \& Molavi, H. (2019). A new model for assessing the impact of the urban intelligent transportation system, farmers' knowledge and business processes on the success of green supply chain management system for urban distribution of agricultural products. Journal of Retailing and Consumer Services, (50), 154-162. https://doi.org/10.1016/j. jretconser.2019.05.007.

5. Bakker, C., Zaitchik, B.F., Siddiqui, S.A., Hobbs, B.F., Broaddus, E.T., Neff, R.A., Haskett, J.D., \& Parker, C. L. (2018). Shocks, seasonality, and disaggregation: Modelling food security through the integration of agricultural, transportation, and economic systems. Agricultural Systems, (164), 165-184. https://doi.org/10.1016/j.agsy.2018.04.005. 6. Lee, G., Lee, H.-W., \& Lee, J. (2015). Greenhouse gas emission reduction effect in the transportation sector by urban agriculture in Seoul, Korea. Landscape and Urban Planning, (140), 1-7. https://doi. org/10.1016/j.landurbplan.2015.03.012.

7. Wu, J., \& Haasis, H. D. (2018). The freight village as a pathway to sustainable agricultural products logistics in China. Journal of Cleaner Production, (196), 1227-1238. https://doi.org/10.1016/j.jclepro.2018.06.077. 8. Sun, J., Tang, J., Fu, W., Chen, Z., \& Niu, Y. (2020). Construction of a multi-echelon supply chain complex network evolution model and robustness analysis of cascading failure. Computers \& Industrial Engineering, (144), 106457. https://doi.org/10.1016/i.cie.2020.106457. 9. Dai, M., \& Liu, L. (2020). Risk assessment of agricultural supermarket supply chain in big data environment. Sustainable Computing: Informatics and Systems, (28), 100420. https://doi.org/10.1016/j.suscom.2020.100420.

10. Huo, L., Guo, H., Cheng, Y., \& Xie, X. (2020). A new model for supply chain risk propagation considering herd mentality and risk preference under warning information on multiplex networks. Physica A: Statistical Mechanics and its Applications, (545), 123506. https:// doi.org/10.1016/j.physa.2019.123506

11. Liu, H., Yang, R., Wu, J., \& Chu, J. (2021). Total-factor energy efficiency change of the road transportation industry in China: A stochastic frontier approach. Energy, (219), 119612. https://doi. org/10.1016/j.energy.2020.119612.

12. Fierro, L. H., \& García, J. I. (2020). Modelling of a multi-agent supply chain management system using Colored Petri Nets. Procedia Manufacturing, (42), 288-295. https://doi.org/10.1016/j.promfg.2020.02.095. 13. Yan, B., Chen, X., Cai, C., \& Guan, S. (2020). Supply chain coordination of fresh agricultural products based on consumer behavior. Computers \& Operations Research, (123), 105038. https://doi. org/10.1016/i.cor.2020.105038

14. Mehmann, J., \& Teuteberg, F. (2016). The fourth-party logistics service provider approach to support sustainable development goals in transportation - a case study of the German agricultural bulk logistics sector. Journal of Cleaner Production, (126), 382-393. https://doi. org/10.1016/i.jclepro.2016.03.095.

15. Agrawal, A. K., \& Yadav, S. (2020). Price and profit structuring for single manufacturer multi-buyer integrated inventory supply chain under price-sensitive demand condition. Computers \& Industrial Engineering, (139), 106208. https://doi.org/10.1016/j.cie.2019.106208.

16. Magalhães, V., Ferreira, L. M., \& Silva, C. (2021). Using a methodological approach to model causes of food loss and waste in fruit and vegetable supply chains. Journal of Cleaner Production, (283), 124574. https://doi.org/10.1016/j.jclepro.2020.124574.

17. Liu, L., Wang, H., \& Xing, Sh. (2019). Optimization of distribution planning for agricultural products in logistics based on degree of maturity. Computers and Electronics in Agriculture, (160), 1-7. https:// doi.org/10.1016/j.compag.2019.02.030.

18. Moubed, M., Boroumandzad, Y., \& Nadizadeh, A. (2021). A Dynamic model for deteriorating products in a closed-loop supply chain. Simulation Modelling Practice and Theory, (108), 102269. https://doi. org/10.1016/j.simpat.2021.102269.

19. Darmawan, A., Wong, H.W., \& Thorstenson, A. (2021). Supply chain network design with coordinated inventory control. Transportation Research Part E: Logistics and Transportation Review, (145), 102168. https://doi.org/10.1016/j.tre.2020.102168.

20. Sabraliev, N., Abzhapbarova, A., Nugymanova, G., Taran, I., \& Zhanbirov, Zh. (2019). Modern aspects of modeling of transport routes in Kazakhstan. News of the National Academy of sciences of the Republic Kazakhstan, 2(434), 62-68. https://doi.org/10.32014/2019.2518170X.39.

21. Sładkowski, A., Utegenova, A., Kolga, A. D., Gavrishev, S. E., Stolpovskikh, I., \& Taran, I. (2019). Improving the efficiency of using dump trucks under conditions of career at open mining works. Nau- kovyi Visnyk Natsionalnoho Hirnychoho Universytetu, (2), 36-42. https://doi.org/10.29202/nvngu/2019-2/8.

22. Naumov, V. (2018). Modeling demand for freight forwarding services on the grounds of logistics portals data. Transportation Research Procedia, 30, 324-331. https://doi.org/10.1016/j.trpro.2018.09.035.

\section{Вибір структури логістичного ланщюга для перевезень насипних вантажів: приклад Республіки Казахстан}

\author{
Б. Рамазан ${ }^{1}$, Р. Муссалієва ${ }^{2}$, 3. Бітілєуова ${ }^{1}$, \\ B. Наумов ${ }^{3}$, I. Tаран ${ }^{4}$
}

1 - Казахська Академія транспорту та комунікації імені М. Тинишпаєва, м. Алмати, Республіка Казахстан 2 - Університет «Туран», м. Алмати, Республіка Казахстан

3 - Краківський політехнічний університет імені Т. Костюшко, м. Краків, Республіка Польща

4 - Національний технічний університет «Дніпровська політехніка», м. Дніпро, Україна, e-mail: $\underline{\operatorname{taran} 7077 @}$ gmail.com

Мета. Стаття спрямована на розробку методології вибору найкращої доступної структури логістичного ланцюга для доставки насипних вантажів.

Методика. Системний підхід використовується для формалізації задачі вибору оптимальної структури логістичного ланцюга: за сумарними витратами визначається цільова функція, альтернативні структури логістичного ланцюга й чисельні параметри потоку заявок (відстань доставки та вага партії вантажу) визначені як керуючі змінні, а випадкові змінні, що представляють технологічні параметри процесів обслуговування, використовуються для врахування впливу навколишнього середовища на логістичний ланцюг. Математична модель визначає функціональну залежність сумарних витрат суб'єктів у ланцюгу доставки від параметрів потоку заявок для двох альтернативних структур: доставка з перевалкою в одному вантажному терміналі й доставка за участі двох терміналів. На підставі функціонального аналізу ми визначаємо діапазони параметрів потоку заявок, для яких використання конкретної структури логістичного ланцюга характеризується мінімальними сумарними витратами.

Результати. Експериментальні дослідження, проведені з урахуванням двох альтернативних структур логістичного ланцюга, показали, що оптимальне рішення варіюється в залежності від значень параметрів заявок. Отримані результати дозволяють стверджувати, що діапазони числових параметрів потоку заявок можуть бути визначені для обгрунтування оптимальної структури логістичного ланцюга доставки сипучих вантажів.

Наукова новизна. У роботі вперше встановлені залежності загальних логістичних витрат від дальності доставки та ваги партії як параметрів потоку заявок на перевезення насипних вантажів.

Практична значимість. Запропонований методичний підхід може бути використаний експедиторами для обгрунтування оптимального варіанту серед наявних альтернативних структур логістичного ланцюга для доставки вантажів із заданими відстанню доставки та вагою партії вантажу.

Ключові слова: структура логістичного ланцюга, експедирування вантажів, сумарні логістичні витрати, потік заявок

Recommended for publication by V.V.Slesaryev, Doctor of Technical Sciences. The manuscript was submitted 10.10.20. 